\title{
ІННОВАЦІЇ В ПУБЛІЧНОМУ УПРАВЛІННЯ ТА АДМІНІСТРУВАННІ: Е-УРЯДУВАННЯ
}

\author{
Лукаш Світлана Миколаївна \\ кандидат економічних наук \\ Сумський національний аграрний університет (м.Суми,Україна) \\ ORCID:0000-0003-1948-7683 \\ svitlana.lukash@gmail.com
}

Бричко Аліна Михайлівна

кандидат економічних наук, доцент

Сумський національний аграрний університет (м.Суми,Україна)

ORCID:0000-0003-4902-1403

alinkabrychko@gmail.com

\begin{abstract}
Ефективне управління будь-якою галуззю у сучасних умовах всеохоплюючої діджиталізації неможливе без широкого застосування сучасних інструментів електронного урядування, зокрема автоматизації обробки великих об'ємів даних та інформаційно-аналітичного забезпечення прийняття управлінських рішень, оптимізації та автоматизації адміністративних процесів, запровадження електронних форм взаємодії уряду з громадянами та бізнесом.
\end{abstract}

Ключові слова: публічне управління, адміністрування, інновації, діджиталізація, електронне урядування.

DOI: https://doi.org/10.32845/bsnau.2019.1.13

Вступ

Наразі в усьому світі дуже активно відбувається процес впровадження інновацій та експериментів в центральній та місцевій владі з метою удосконалення державного управління й посилення до нього довіри, особливо це стосується сфери надання послуг. Обмін та обмін цим інноваційним досвідом може створити сукупність "нових знань", до яких можуть звернутися країни у всьому світі. Стаття присвячена аналізу успішного досвіду та найкращих практик в державному управлінні, а також вивчення їх потенціалу для адаптаціï.

Найкращі практики зосереджуються на ряді областей, включаючи: стратегічне управління людськими ресурсами, лідерство, комунікація та партнерство, інновації у наданні соціальних послуг, управління закупівлями, інновації у фіскальному управлінні, державне управління та розвиток приватного сектору, децентралізація, етика та підзвітність в державному управлінні. Увага до інновацій у щоденній практиці державного управління відображається у збільшенні кількості наукових статей на тему інновацій.

Інновації - такі як абсолютно новий продукт або новий погляд на стару проблему - є радикальним розривом з минулим (Brown and Osborne, 2012). Цей радикальний розрив $€$ основною відмінністю між інноваціями та вдосконаленнями. Відповідними типами інновацій є: (1) інноваційні процеси (розвиток муніципалітету або про різні технологічні інновації); (2) нововведення товарів чи послуг; (3) інновації в управлінні (зокрема, надання громадянам більшої самостійності у виборі); та (4) концептуальні нововведення.

Розглядаючи інновації, очевидно, що наукова перспектива, яку використовували для розуміння цих процесів, значно змінилася. Спочатку Джозеф Шумпетер (1942), засновник теорії інновацій, пов'язував інновацію з винаходом і підприємництвом. Однак, щоб реалізувати та прийняти винаходи, такі винаходи потрібно було "продати". Отже, успішність інновації напряму залежала від підприємництва, підкреслюючи індивідуальні якості винахідника / підприємця. Пізніше, у 60-х роках, інновації розглядалися як систематичний підхід, який можна було б організувати та запрограмувати: якби у вас були необхідні ресурси в одному місці, інновації можуть статися. Тому організації починають створювати спеціалізовані науково-дослідні підрозділи (Друкер, 1985). Поступово вчені почали говорити про появу так званого "середовища інновацій" (Беккерс, 2011; Кастеллс, 1996). Цей підхід підкреслює важливість того факту, що інновації відбуваються не лише у конкретних організаціях. Організації повинні охоче ділитися життєвими ресурсами (як ідеї, знання, фонди та люди) через організаційні межі. Інновації в цих "середовищах" розглядаються як процес співпраці між зацікавленими сторонами з метою вирішення суспільних викликів (Вурберг, 2015). Ось чому в літературі про інновації йдеться про «відкриту інновацію», на відміну від досить однобічного та закритого підходу попередніх двох підходів (Мейєр, Болівар, 2016; Мергель, Десоуза, 2013)

Слід відмітити, що визначальна роль у підвищенні якості та інновації державних адміністрацій, прискоренні використання широкомасштабного публічного та приватного секторів, надійній ідентифікації довірчих послуг на єдиному цифровому ринку припадає саме на електронне врядування. Використання е-врядування, інтеграція в єдиний цифровий ринок дозволить підвищити якість, ефективність послуг врядування.

Ефективне електронне врядування зможе забезпечити широкий спектр переваг, включаючи більшу ефективність та економію як для урядів, так і підприємств; підвищення відкритості та прозорості уряду; більшу участь громадян у політичному житті.

ICT вже широко використовуються урядовими органами різних країн але це не просто ніж інструмент. Воно також передбачає переосмислення організації та процесів, зміну поведінки з метою підвищення ефективності надання публічних послуг населенню. Ретельно виважене та добре впроваджене електронне урядування дасть можливість громадянам, підприємствам та організаціям здійснювати свій бізнес з урядом легше, швидше, прозоріше та за менших витрат.

Потенційна економія коштів $є$ величезною. Наприклад, у Данії електронне виставлення рахунків заощаджує

Вісник Сумського національного аграрного університету

Серія «Економіка і менеджмент», випуск 1 (79), 2019 
платникам податків 150 мільйонів євро, а бізнесу 50 мільйонів $€ в$ ро на рік. Якщо проаналізувати $Є С$, то щорічна економія може перевищує 50 мільярдів євро. Тільки в Італії системи електронних закупівель скоротили витрати на понад 3 млрд. євро.

Транскордонні цифрові публічні послуги дозволяють інтегруватись до єдиного цифрового ринку: на внутрішньому ринку Європейського Союзу люди зможуть вільно пересуватися з бізнес чи приватних причин - тому їм потрібно мати можливість легко працювати з державними послугами за межами своєї країни. На сьогодні системи ICT вже лежать в основі урядових процесів, але все ще потрібно докласти зусиль для того, щоб вони продовжували покращувати надання державних послуг.

В рамках своєї стратегії Європейська Комісія вживає конкретних дій з розвитку транскордонних цифрових державних послуг. Вони включають, але не обмежуються цим, створення європейських інтероперабельних платформ, таких як загальна основа для управління електронною ідентичністю громадян (elD), та сприяння інноваціям через Програму конкурентоспроможності та інновацій (фінансування великих пілотних проектів та проектів електронної участі) .

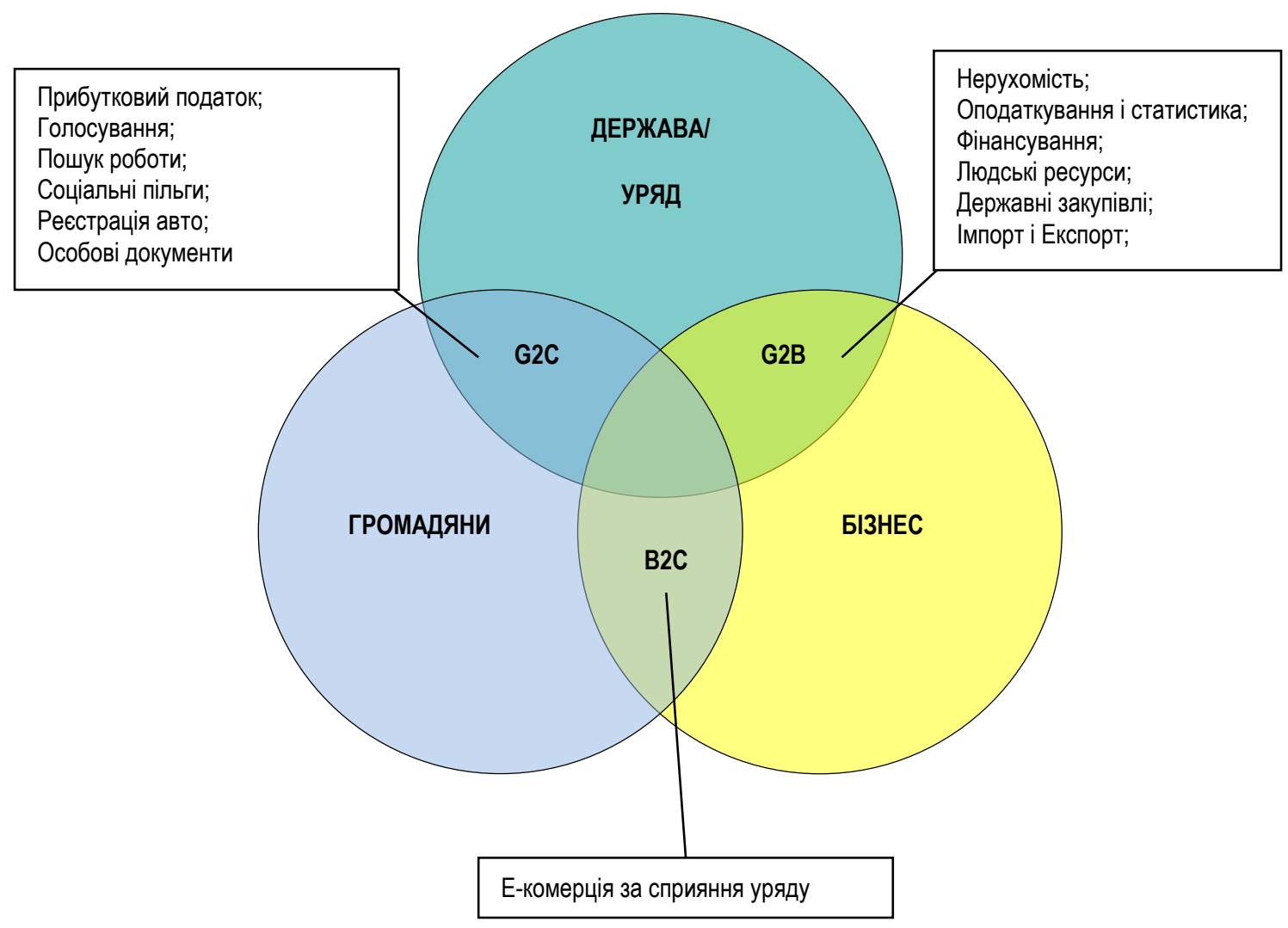

С2С - спілки, об'єднання;

Puc. 1.1. Схема е-урядування

$\mathrm{G} 2 \mathrm{G}$ - міжурядова взаємодія;

B2B - торгівельні площадки.

У е-врядування три основні рівні реалізації, які охоплюють майже всі сфрери суспільного життя:

Government 2 Citizens або G2C (уряд-громадяни)

Взаємодія між державою і громадянином стає простіше. Це дозволяє уникнути бюрократичну рутину з нескінчен-

ними вартою в чергах і скорочує витрати держави. Наприклад, при втраті паспорта обивателю досить методом одного кліка запросити через ресурс відновлення документа і отримати його в зазначений термін. Те ж стосується реєстрації автомобіля та житла, отримання субсидій і соціальної допомоги. 
Government 2 Business або G2B (уряд-бізнес)

Спрощує процедури реєстрації бізнесу та взаємодії з податковою для підприємців. Участь в тендерах автоматизується і стає більш прозорим. Впровадження сервісів G2B дозволить лікувати «тіньові процеси», які виникають по ходу створення і становлення на ноги підприємництва в Україні.

Government 2 Government aбо G2G (уряд-уряд)

Налагоджує і прискорює документообіг між відомствами, допомагає поліпшити ефективність роботи держапарату, спростити кооперацію регіональних управлінь і територіальних підрозділів.

Для оцінювання стану розвитку е-урядування у світі показовим $€$ Індекс розвитку електронного ресурсу (The UN E-Government Development Index) - єдиний рейтинг розвитку електронного уряду в усьому світі, що надається ООН. Дане опитування оприлюднюється ООН кожні два роки. Видання 2018 року: «Надання електронного уряду для підтримки трансформації до сталого та стійкого суспільства» було оприлюднено 19 липня 2018 року.

Індекс розвитку електронного уряду (EGDI) - це складений індекс оцінювання, заснований на середньозваженому рівні трьох нормованих індексів:

- Індекс інфраструктури телекомунікацій (ТII)б який базується на даних, наданих Міжнародним союзом телекомунікацій (ITU);

- Індекс людського капіталу $(\mathrm{HCl})$, який заснований на даних, наданих Організацією Об'єднаних Націй з питань освіти, науки та культури (ЮНЕСКО);

- Індекс Інтернет-сервісів (OSI), який заснований на даних, зібраних із незалежного опитування, проведеного UNDESA, який оцінює національну присутність в Інтернеті всіх 193 держав-членів Організації Об'єднаних Націй. Зазначений індекс оцінює розвиток електронного уряду на національному рівні. Він вимірює використання країнами інформаційних та комунікаційних технологій для надання державних послуг.

Індекс фіксує масштаби та якість онлайн-послуг, стан телекомунікаційної інфрраструктури та наявний людський потенціал. 3 огляду на міжнародний досвід розвиток електронного урядування $є$ одним з основних факторів забезпечення успішності реформування та підвищення конкурентоспроможності країни. Рефоома будь-якої галузі в сучасних умовах спрямована на широке використання сучасних інфоормаційнокомунікаційних технологій для досягнення необхідного рівня ефрективності та результативності. Адже саме інструменти еурядування здатні забезпечити значне покращення якості обслуговування фізичних і юридичних осіб та підвищення відкритості, прозорості та ефрективності діяльності органів державної влади та органів місцевого самоврядування (далі - органи влади). Крім того, запровадження електронного урядування $є$ базовою передумовою для розбудови в Україні ефективних цифрової економіки і цифррового ринку та його подальшої інтеграції до єдиного цифрового ринку ЄC (EU Digital Single Market Strategy).

Таблиця 1.1

Індекс розвитку електронного уряду 2018, ТОП-10-країн

\begin{tabular}{|l|c|}
\hline \multicolumn{2}{|c|}{ Індекс розвитку електронного уряду - Тор 10 Країн } \\
\hline \multicolumn{2}{|c|}{ Країна } \\
\hline Данія & Index \\
\hline Австралія & 0.9150 \\
\hline Республіка Корея & 0.9053 \\
\hline Великобританія & 0.9010 \\
\hline Швеція & 0.8999 \\
\hline Фінляндія & 0.8882 \\
\hline Сінгапур & 0.8815 \\
\hline Нова Зеландія & 0.8812 \\
\hline Франція & 0.8806 \\
\hline Японія & 0.8790 \\
\hline \hline & 0.8783 \\
\hline Україна & \\
\hline
\end{tabular}

Україна займає в даному рейтингу 82-гу позицію.

Індекс пропонує короткий огляд тенденцій розвитку електронного уряду в країнах світу:

Європейські країни очолюють розвиток електронного уряду в усьому світі; Америка та Азія мають майже рівне становище на високому та середньому рівнях індексу електронного уряду, при цьому країни Афррики продовжують боротися за поліпшення свого статусу електронного уряду.

Вісім з 11 нових країн, які у 2018 році приєдналися до групи з найвищими показниками, є з Європи (Білорусь, Греція, Ліхтенштейн, Мальта, Монако, Польща), а дві - з Азії (Кіпр та Казахстан).
Прогрес у розвитку електронного уряду в Америці та Азії хоч і повільний, але помітний. Дві третини країн Азії (31 3 47) та майже половина країн Америки (15 з 35) мають середній показник EGDI у світі на рівні 0,55.

Уругвай - єдина латиноамериканська країна з дуже високими показниками EGDI, приєднавшись до двох інших провісників у регіоні Америки в цій групі - США та Канада.

Лише 4 країни з 54 в Афрриці набирають вищого рівня, ніж середній показник EGDI у світі - 0,55, тоді як у 14 країн дуже низькі показники EGDI нижче 0,25. Ці країни також мають низький дохід і можуть зіткнутися з обмеженнями у виділенні необхідних ресурсів для розвитку електронного уряду. 
Розбіжність у рівні розвитку електронного уряду також $€$ досить високою серед країн Африки та Океанії. Австралія та Нова Зеландія - єдині дві країни в Океанії, які набирають відповідно 0,9053 та 0,8806. Оцінки для інших 12 країн складають від 0,2787 до 0,5348, що нижче середнього у світі 0,55.

Як правило, існує позитивна кореляція між рівнем доходу країни та рейтингом електронного урядування. Країни з високим рівнем доходу мають дуже високі або високі оцінки EGDI. Однак це не є універсальним. Двадцять дві країни з середнім рівнем доходу та 39 країн з нижчим середнім рівнем доходу мають показники EGDI нижче за загальний показник EGDI, a 10 країн нижчої групи з середнім рівнем доходу мають бали вище світового середнього показника EGDI. 3 іншого боку, країни з низьким рівнем доходу продовжують відставати через відносно низький рівень розвитку всіх компонентів Індексу.

Вперше у 2018 році основним учасником покращення результатів EDGI у всіх групах доходів $€$ розвиток онлайнсервісів, що дозволяє припустити, що в усьому світі спостерігається стабільний прогрес у вдосконаленні електронного уряду та надання публічних послуг в Інтернеті.

Усі 193 держави-члени Організації Об'єднаних Націй мали національні портали та резервні системи для автоматизації основних адміністративних завдань, а 140 надавали принаймні одну транзакційну послугу в Інтернеті. Тенденція вдосконалення транзакційних онлайн-сервісів сильна та послідовна у всіх оцінюваних категоріях, причому три найпоширеніші послуги - це оплата за комунальні послуги (140 країн), подання податку на прибуток (139 країн) та реєстрація нового бізнесу (126 країн).

Все більше країн надають онлайн-сервіси, націлені на найбільш вразливі групи. 3 регіональної точки зору, Європа продовжує лідирувати в наданні послуг в Інтернеті для всіх вразливих груп, які охоплюють майже універсальне охоплення в регіоні або понад 80 відсотків усіх європейських країн.

Кількість країн, які надають онлайн-сервіси за допомогою електронних листів, оновлень каналів SMS / RSS, мобільних додатків та форм для завантаження, зростає у всіх секторах. Наприклад, до 176 країн надають в Інтернеті архівну інформацію порівняно з 154 у 2016 році.

У травні поточного року ключові громадські організації та розробники рішень електронних послуг в Україні об'єдналися в незалежну коаліцію електронної держави (E Government Coalition) для підтримки прозорості влади, боротьби з корупцією та створення нових електронних рішень. Електронний уряд - це ключ до прозорості і підзвітності державного управління. метою коаліції $€$ допомогти органам влади швидше запускати рішення по прозорості бюджетів, електронного участі і послуг; консультувати їх як запустити рішення, використовуючи вже існуючі інструменти, а також створити для населення єдиний інформаційний простір і платформу вже існуючих послуг. В коаліцію, зокрема, увійшли: антикорупційна організація Transparency International, фонди "Відродження" та "Східна Європа", громадські організації "Реанімаційний пакет реформ" і "Електронна демократія", представники програм EGAP і TAPAS, "Нова країна", Центр розвитку інновацій , Стратегічна група радників з підтримки реформ в Україні (SAGSUR), Офіс ефективного регулювання BRDO і постачальники електронних рішень, серед яких Helsi.me, iGov, ProZorro, YouControl.
Уряд схвалив Концепцію розвитку електронного урядування в Україні. Документом визначено напрями, механізми і строки формування ефективної системи електронного урядування в Україні для задоволення інтересів та потреб фізичних і юридичних осіб, вдосконалення системи державного управління, підвищення конкурентоспроможності та стимулювання соціально-економічного розвитку держави. Реалізація Концепції дасть змогу: підвищити ефективність роботи органів державної влади й органів місцевого самоврядування та досягти якісно нового рівня управління державою, що базується на принципах результативності, ефективності, прозорості, відкритості, доступності, довіри та підзвітності; покращити якість надання публічних послуг фізичним та юридичним особам відповідно до європейських вимог, а також забезпечити необхідну мобільність й конкурентоспроможність громадян та суб'єктів господарювання у сучасних економічних умовах; мінімізувати корупційні ризики при виконанні владних повноважень; покращити інвестиційну привабливість, діловий клімат та конкурентоспроможність країни; стимулювати соціально-економічний розвиток в Україні. Реалізація Концепції передбачена на період до 2020 року та покликана підтримати координацію та співпрацю органів державної влади та органів місцевого самоврядування для досягнення необхідного рівня есрективності та результативності розвитку електронного урядування, просування ідеї реформування державного управління та децентралізації на базі широкого використання сучасних інформаційно-комунікаційних технологій в усій країні, а також сприяти реалізації першочергових пріоритетів, визначених Стратегією сталого розвитку "Україна 2020".

Реалізація Концепції здійснюється за такими основними принципами:

- цифровий за замовчуванням - забезпечення будь-якої діяльності органів влади (у тому числі надання публічних послуг, забезпечення міжвідомчої взаємодії, взаємодії з фізичними та юридичними особами, інформаційно-аналітичної діяльності) передбачає електронну форму реалізації як пріоритетну, а планування та реалізацію будь-якої реформи, проекту чи завдання - із застосуванням інформаційно-комунікаційних технологій;

- одноразове введення інформації - реалізація підходу, за якого фрізичні та юридичні особи лише один раз подають інформацію до органів влади, а у подальшому ця інформація повторно використовується органами влади для надання публічних послуг та виконання інших владних повноважень з дотриманням вимог захисту інформації та персональних даних;

- сумісність за замовчуванням - здійснення проектування та функціонування інформаційно-телекомунікаційних систем в органах влади відповідно до єдиних відкритих вимог та стандартів для забезпечення їх подальшої сумісності та електронної взаємодії та повторного використання;

- доступність та залучення громадян;

- відкритість та прозорість;

- довіра та безпека.

В епоху активної діджиталізації повсякденне життя громадян стає дедалі все більш “цифровим", що передбачає високий рівень очікувань від діяльності органів влади, зокрема розвитку сучасних електронних форм взаємодії, прозорості та відкритості діяльності, залучення громадян до прий-

Вісник Сумського національного аграрного університету 
няття управлінських рішень. На сучасному етапі розвитку країни вбачається можливим використання консервативного або трансформаційного шляхів для подальшого розвитку електронного урядування. Консервативний шлях має еволюційний характер та суттєво не змінює існуючі принципи та цілі розвитку наявної інфраструктури електронного урядування, що може призвести до відставання від світових темпів розвитку.

Натомість трансформаційний шлях, який пропонується в рамках даної Концепції, має революційний характер та робить акцент на посиленні функціональних можливостей електронного урядування та зниженні витрат органів влади на реалізацію владних повноважень шляхом застосування сучасних інноваційних підходів, методологій та технологій (у тому числі Інтернету речей, хмарної інфрраструктури, Blockchain, Mobile ID, shareding economy, просування методики опрацювання даних великих обсягів (Big Data), нормативно-правового врегулювання принципів "цифровий за замовчуванням", "одноразове введення інформаціі" та "сумісність за замовчуванням", а також застосування перспективних фрорм організації виконання завдань і проектів розвитку електронного урядування, зокрема публічно-приватного партнерства.

Для досягнення мети Концепції слід забезпечити виконання комплексних заходів за такими напрямами:

- модернізація публічних послуг та розвиток взаємодії влади, громадян і бізнесу за допомогою інформаційно-комунікаційних технологій;

- модернізація державного управління за допомогою інформаційно-комунікаційних технологій;

- управління розвитком електронного урядування.

Розвиток та поширення сучасних інформаційно-комунікаційних технологій створює нові можливості для забезпечення взаємодії та співпраці органів влади, громадян і бізнесу, високоякісного обслуговування фрізичних та юридичних осіб державою, у тому числі залучення громадян до проектування електронних послуг та отримання якісного зворотного зв'язку.

Розвиток та підтримка доступних та прозорих, безпечних та не корупційних, найменш затратних, швидких та зру- чних електронних послуг дасть змогу покращити якість надання публічних послуг фізичним та юридичним особам, підвищити їх мобільність та конкурентоспроможність, зменшити корупційні ризики та забезпечити, щоб електронні послуги обслуговували економіку майбутнього.

Пріоритетними напрямками розвитку електронного урядування в Україні є:

- запровадження електронних послуг, у тому числі адміністративних, в усіх сферах суспільного життя, а також надання інтегрованих електронних послуг за життєвими та бізнес-ситуаціями;

- реалізація принципу єдиного вікна ("one-stop-shop") шляхом забезпечення розвитку та функціонування Єдиного державного порталу адміністративних послуг як єдиної точки доступу фізичних та юридичних осіб до електронних послуг;

- розвиток електронних публічних закупівель, електронних договорів і рахунків, електронних аукціонів;

- стимулювання використання електронних послуг фізичними та юридичними особами

Висновки. Активне впровадження інформаційно-комунікаційних технологій в систему суспільно-політичних відносин значно розширює можливості громадян щодо їх участі в процесах державного управління та впливу на прийняття управлінських рішень, створює умови для формування якісно нового рівня взаємодії органів влади та громадян.

Державне управління в Україні потребує модернізації шляхом реінжинірингу існуючих та проектування оновлених адміністративних процесів в органах влади, оптимізованих 3 використанням сучасних інформаційно-комунікаційних технологій, спрямованих на електронну взаємодію та спільну роботу, відкритість та прозорість для громадян.

Запровадження автоматизованого обміну даними між інформаційно-телекомунікаційними системами органів влади дасть змогу забезпечити підвищення ефективності роботи органів влади шляхом скорочення часу отримання необхідних даних, покращення якості та актуальності опрацьованих даних, ліквідації багаторазового збору та дублювання даних в різних інформаційних системах, покращення доступності інформаційних ресурсів та їх систематизацію.

\section{Cnuсок літературu:}

1.Bekkers, VJJM, Edelenbos, J, Steijn, AJ (2011) Innovation in the Public Sector. London: Palgrave Macmillan

2.Brown, K, Osborne, SP (2012) Managing Change and Innovation in Public Service Organizations. London: Routledge.

3.Carmeli, A, Gelbard, R, Gefen, D (2010) The importance of innovation leadership in cultivating strategic fit and enhancing firm performance. The Leadership Quarterly 21(3): 339-349.

4.Castells, M (1996) The Rise of the Network Society. Cambridge: Blackwell.

5.De Vries, H, Bekkers, VJJM, Tummers, LG (2016) Innovation in the public sector: A systematic review and future research agenda. Public Administration 94(1): 146-166.

6.Drucker, P (1985) Innovation and Entrepeneurship: Practice and Principles. New York, NY: Harper.

7.Hartley, J (2005) Innovation in governance and public services: Past and present. Public Money and Management 25(1): $27-34$.

8.Klijn, EH, Koppenjan, J (2015) Governance Networks in the Public Sector. London: Routledge.

9.March, JG, Olsen, JP (2010) Rediscovering Institutions. New York: Simon and Schuster.

10. Meijer, A, Bolívar, MPR (2016) Governing the smart city: A review of the literature on smart urban governance. International Review of Administrative Sciences 82(2): 392-408.

11. Mergel I, and Desouza KC (2013) Implementing open innovation in the public sector: The case of Challenge. gov. Public Administration Review 73(6): 882-890.

12. Moore, M, Hartley, J (2008) Innovations in governance. Public Management Review 10(1): 3-20.

13. Schumpeter, JA (1942) Capitalism, Socialism, and Democracy. New York, NY: Harper.

14. Sørensen, E, Torfing, J (2011) Enhancing collaborative innovation in the public sector. Administration \& Society 43(8): 842-868.

Вісник Сумського національного аграрного університету

Серія «Економіка і менеджмент», випуск 1 (79), 2019 
15. Tummers, LG, Knies, E (2016) Measuring public leadership: Developing scales for four key public leadership roles. Public Administration 94(2): 433-451.

16. Voorberg, WH, Bekkers, VJ, Tummers, LG (2015) A systematic review of co-creation and co-production: Embarking on the social innovation journey. Public Management Review 17(9): 1333-1357.

17. Концепція розвитку електронного урядування в Україні. Режим доступу: https://www.kmu.gov.ua/ua/npas/250287124

18. Рейтинг країн світу за рівнем розвитку електронного урядування. Режим доступу: http://kolokol.od.ua/wpcontent/uploads/2015/12/Screenshot_11.jpg

Lukash S.M., PhD, Sumy National Agrarian University (Sumy, Ukraine)

Brychko A.M., PhD, Associate Professor, Sumy National Agrarian University (Sumy, Ukraine)

Innovations in public administration and administration: e-governance

Effective management of any industry in the current context of comprehensive digitization is impossible without the widespread use of modern e-government tools, including automation of processing large volumes of data and information-analytical support for administrative decision-making, optimization and automation of administrative processes, introduction of electronic forms of interaction and business.

Currently, the process of introducing innovations and experiments in central and local government is very active around the world, with a view to improving public administration and building confidence in it, especially in the area of service delivery. Sharing these innovative experiences can create a pool of "new knowledge" that can be accessed by countries around the world. The article is focused on the analysis of successful experiences and best practices in public administration, as well as exploring their potential for adaptation. Best practices focus on a number of areas, including: strategic human resource management, leadership, communication and partnership, innovation in social services, procurement management, innovation in fiscal governance, public administration and private sector development, decentralization, ethics and accountability in public administration.

The active introduction of information and communication technologies into the system of socio-political relations significantly increases the opportunities of citizens to participate in the processes of public administration and influence on decision-making, creates conditions for the formation of a qualitatively new level of interaction between authorities and citizens.

State governance in Ukraine needs modernization by re-engineering existing and designing updated administrative processes in government, optimized using modern information and communication technologies aimed at electronic interaction and teamwork, openness and transparency for citizens.

Introduction of automated data exchange between the information and telecommunication systems of the authorities will allow to increase the efficiency of work of the authorities by reducing the time of obtaining the necessary data, improving the quality and relevance of the processed data, eliminating multiple data collection and duplication in different information systems, improving the availability of information resources and their systematization.

Key words: public administration, administration, innovation, digitization, e-government

Дата надходження до редакції: 15.01.2019 р. 